\title{
Fatty acid composition as one of the markers of state and functioning of branching Baikal sponge
}

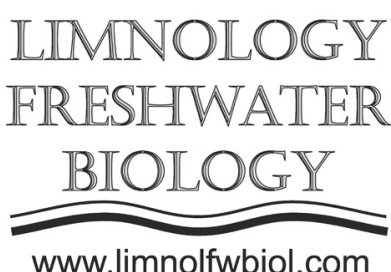

\author{
Nikonova A.A.*, Khanaev I.V., Glyzina O.Yu. \\ Limnological Institute Siberian Branch Russian Academy of Sciences, Ulan-Batorskaya St. 3, 664033, Irkutsk, Russia
}

\begin{abstract}
The fatty acid composition of visually health and sick Lubomirskia baicalensis sponges from Lake Baikal (years of 2016 and 2018) was determined. Sponges collected in 2018 had an abnormality of demospongic acid synthesis. Demospongic acids are of antibiotic activity and protect sponges. In vitro, there was an increase in the concentrations of the palmitic, oleic, linoleic and $\alpha$-linolenic sponge acid under stress. These substances are responsible for cell membrane repairing and antibiotically active. During three weeks, there were also demospongic acid synthesis termination and appearance of disease precursors was noted.
\end{abstract}

Keywords: Lake Baikal, sponge, Lubomirskia baicalensis, FAME, GC-MS

Lubomirskia baicalensis is a freshwater endemic Lake Baikal sponge of the Lubomirskiidae family. It covers the stony bottom of the littoral benthic zone at depths from 3-4 up to $30-40 \mathrm{~m}$. Due to of the great biomass of Lubomirskiidae in Lake Baikal and ability of sponge to pass large volumes of fresh water through its body, the filtration activity of sponges is of great importance in the processes of purification of a water reservoir (Kupchinsky et al., 2019). Sponge skeleton has unique physical-chemical properties and can be an adsorbent with high sorption capacity, as our experiments show. Analysis in situ of sorption properties of the Baikal $L$. baicalensis shows that the sponges can sorbs up to $0.1-0.5 \mathrm{mg}$ of synthetic organic pollutants per $1 \mathrm{~g}$ dry weight of sponge dried at room temperature during $72 \mathrm{~h}(n=25)$.

The appearance of abnormal pink sponges in Lake Baikal was recorded in 2011 (Bormotov, 2011). By 2014, diseases and mortality of different sponge species have increased rapidly and covered the littoral zone through the lake perimeter (Khanaev et al., 2018). Causes of disease, as well as mechanisms of functioning and adaptation of sponges and other species of low phylogenetic levels have poorly studied yet. Different causes of disease can be suggested such as anthropogenic effect and following microbial invasion. Biochemical analysis and experiments in situ and in vitro can clear a reason of this phenomenon. There are numerous studies on sponge fatty acids (Latyshev et al., 1992; Rod'kina, 2005; Glyzina et al., 2016). To understand processes in organisms of visually health and sick sponges we analyzed fatty acid composition using high accuracy analytical techniques.
Sponge samples were taken in 2016 and 2018 in the southern basin of Lake Baikal. Some samples were placed in aquariums under conditions close to natural. Samples were prepared according to (Nikonova et al., 2020). Lipids were extracted with $1.2 \mathrm{~mL}$ of Folch mixture using an ultrasound bath for $5 \mathrm{~min}$, and 0.35 $\mathrm{mL}$ of distilled water was added. Then the mixture was emulsified and centrifuged. Recovery was $\sim 95 \%$. Fatty acid (FA) methylation was carried out under soft conditions $\left(55^{\circ} \mathrm{C}, 1.5 \mathrm{hr}, 2-\%\right.$ sulfuric acid solution in methanol). Esterified FAs were methylated separately in alkaline medium at $25{ }^{\circ} \mathrm{C}$. Methyl esters of FAs (FAMEs) were analysed using 6890B GC System, 7000C GC/MS Triple Quad (Agilent, USA) and GC-2010 Plus coupled with FID (Shimadzu, Japan) with Optima17MS GC-columns ( $30 \mathrm{~m} \times 0.25 \mathrm{~mm}$, Macherey-Nagel, Germany).

In 2016, FAME content in L. Baicalensis samples ranged from 8 to $35 \mathrm{mg} / \mathrm{g}$ of dry weight, and more than 60 FAs were found, with 34 FAs being identified reliably. They were saturated (SFA), branched, monounsaturated, polyunsaturated (PUFAs) and demospongic acids with 24-30 carbon atoms, that agrees with (Dembitsky et al., 1993). The SFA content was $\sim 20 \%$ for visually healthy sponges and $\sim 30 \%$ - for sick ones. The bacterial FAs content was $\sim 4 \%$ for all samples, whereas the PUFA content, including the demospongic acid content, was $2-5$ times higher for healthy sponges than for sick ones. In this case, the bacterial FAs content may show the similar state of bacterial symbionts of healthy and sick sponges, whereas the differences in the PUFA content, including demospongic FAs synthesized directly by sponge, might show differences in them. In 2018, the

*Corresponding author.

E-mail address: alenaxis@list.ru (A.A. Nikonova)

(C) Author(s) 2020. This work is distributed under the Creative Commons Attribution 4.0 License. 
FAME content in L. Baicalensis samples was in ranged from 6 to $25 \mathrm{mg} / \mathrm{g}$ dry weight and only 15 FAs were found comparing to 2016 . The SFA content was $\sim 30 \%$. Demospongic acids were not found. The free fatty acid (FFA) content was $\sim 30-50 \%$ that points to high stress.

The FFA content in sponges placed in aquariums at $0-3.6{ }^{\circ} \mathrm{C}$ increased under stress. After two weeks, FFA were not found. Every week we cut sponge branches and soon the visual state of sponges became worse and signs of disease appeared. The FFA content increased up to 80 times during a month. The highest increase was observed for palmitic, linoleic, oleic and $\alpha$-linolenic FAs. Palmitic acid is one of the main components of cell membranes and its content growth can be explained by the repairштп of damaged sponge cells. Oleic acid is an intermediate product for synthesis of demospongic FAs from palmitic acid (Latyshev et al., 1992; Dembitsky et al., 1993; Kornprobst and Barnathan, 2010). Two other acids (Dembitsky et al., 1993; Kornprobst and Barnathan, 2010) are of high antimicrobial activity. Also $\alpha$-linolenic FA can repair destroyed cells. Demospongic FAs were not found in sponges placed in aquariums, as well as in natural ones (2018), though they are of high antibacterial and antifungal activity (Kornprobst and Barnathan, 2010). We can show in vitro and in situ an abnormal synthesis of demospongic acids that most likely causes intense microbial invasion. Stress factor for sponges in situ which destroy their immunity has not clearly determined yet.

\section{Acknowledgements}

The investigation was carried out within the State Task of the Ministry of the Science and High Education of the Russian Federation (no. 0345-2018-0008 "The Estimation and Forecast of Ecological Etate..." and no. 0345-2016-0002 "Molecular Ecology and Evolution..." on the basis of freshwater aquarium complex of Baikal aquatic habitats LIN SB RAS.

\section{References}

Bormotov A.E. 2011. What happened with Baikal sponges? Nauka iz Pervykh Ruk [Science First Hand] 5: 20-23. (in Russian)

Dembitsky V.M., Rezanka T., Kashin A.G. 1993. Comparative study of the endemic freshwater fauna of Lake Baikal - II. Unusual lipid composition of two sponge species Baicalospongia bacillifera and Baicalospongia intermedia (family Lubomirskiidae, class Demospongiae). Comparative Biochemistry and Physiology Part B: Comparative Biochemistry 106(4): 825-831. DOI: 10.1016/0305-0491(93)90037-6

Glyzina O.Yu., Bazarsadueva S.V., Glyzin A.V. et al. 2016. Changes in the lipid composition of freshwater sponges upon rise in habitat temperature. Russian Journal of Ecology 47(2): 211-213. DOI: 10.1134/S1067413616020077

Khanaev I.V., Kravtsova L.S., Maikova O.O. et al. 2018. Current state of the sponge fauna (Porifera: Lubomirskiidae) of Lake Baikal: sponge disease and the problem of conversation of diversity. Journal of Great Lakes Research 44(1): 77-85. DOI: 10.1016/j.jglr.2017.10.004

Kornprobst J.-M., Barnathan G. 2010. Demospongic acids revisited. Marine Drugs 8(10): 2569-2577. DOI: 10.3390/ md8102569

Kupchinsky A.B., Fialkov V.A., Zhdanova G.O. et al. 2019. Absorption of microorganisms by Lubomirskiidae sponges. In: International Multidisciplinary Scientific GeoConference "Hydrology and Water Resources". DOI: 10.5593/sgem2019/3.1/S12.001

Latyshev N.A., Zhukova N.V., Efremova S.M. et al. 1992. Effect of habitat on participation of symbionts in formation of the fatty acid pool of fresh-water sponges of Lake Baikal. Comparative Biochemistry and Physiology Part B: Comparative Biochemistry 102(4): 961-965. DOI: 10.1016/0305-0491(92)90109-5

Nikonova A.A., Shishlyannikov S.M., Shishlyannikova T.A. et al. 2020. Determination of free and esterified fatty acids in hydrocoles of different content of polyunsaturated fatty acids by gas-liquid chromatography. Zhurnal Analiticheskoi Khimii [Jornal of Analytical Chemistry] 75(10): 1310-1321. (in Russian)

Rod'kina S.A. 2005. Fatty acids and other lipids of marine sponges. Russian Journal of Marine Biology 31(6): S49-S60. DOI: $10.1007 / \mathrm{s} 11179-006-0015-3$ 